\title{
PENGARUH EFEK EKSTRAK ETANOL DAUN MURBEI (Morus multicaulis) SEBAGAI ANTIOKSIDAN PADA PARU - PARU TIKUS (Rattus norvegicus) JANTAN YANG DIPAPAR ASAP ROKOK DENGAN PARAMETER HISTOPATOLOGI
}

\author{
Muhammad Asri ${ }^{*}$, Rachmat Kosman ${ }^{\star *}$, Dewi Yuliana ${ }^{* *}$ ) \\ ${ }^{*}$ Sekolah Tinggi Ilmu Kesehatan Mega Rezky Makassar \\ ${ }^{* *}$ Fakultas Farmasi Universitas Muslim Indonesia Makassar \\ Email : asri_muh@rocketmail.com.
}

\begin{abstract}
This research aimed to see antioxidant effect of extract ethanol leaves of Murbei (Morus multicaulis) in the lung hispathology of rats who get cigarette smoke exposure. The research method is have been done with experimental, 25 male rats (Rattus norvegicus) with 2-5 month old, body weigh range 100-200 gram were treated for 31 days. Devide in to 5 groups, $P 1$ positive control (has given food and drink), P2 negative control (with cigarette smoke exposure), P3 (a group treated by cigarette smoke exposure and extract ethanol Murbei $100 \mathrm{mg} / \mathrm{kgBB}$ ), P4 (a group treated by cigarette smoke exposure and extract ethanol Murbei $200 \mathrm{mg} / \mathrm{kgBB})$, P5 (a group treated by cigarette smoke exposure and vitamin E 1,8 mg/kgBB). In 31st day, the mice performed surgery to retrieve organs rat lung histopathology test is then performed. Given ethanol extract of leaves of Murbei (Morus multicaulis) 100 $\mathrm{mg} / \mathrm{kgBB}$ and $200 \mathrm{mg} / \mathrm{kgBB}$ may have an effect as an antioxidant in the lungs of rat (Rattus norvegicus) males.
\end{abstract}

Key words : Cigarette smoke, extract ethanol Murbei, antioxidant.

\section{PENDAHULUAN}

Rokok secara luas telah menjadi salah satu penyebab kematian terbesar di dunia. Diduga hingga menjelang tahun 2030 kematian akibat merokok akan mencapai 10 juta orang pertahunnya. Indonesia merupakan salah satu negara berkembang yang memiliki tingkat konsumsi rokok dan produksi rokok yang tinggi. Menurut bank dunia, konsumsi rokok Indonesia sekitar $6,6 \%$ dari seluruh konsumsi dunia (Depkes, 2005). Diperkirakan dalam satu kali hisapan rokok terdapat 1014 molekul radikal bebas. Radikal bebas tersebut dapat menginaktivasi a1-anti trypsin. Akibatnya, hambatan a1-anti trypsin terhadap elastase berkurang dan terjadilah degradasi jaringan elastis paru (Winarsih, 2007).

Kelainan paru akibat radikal bebas pada rokok akan menyebabkan kelainan pada saluran pernafasan, mulai dari trakea, bronkus dan 
Pengaruh efek ekstrak etanol daun murbei sebagai antioksidan pada paru-paru tikus jantan yang dipapar asap rokok dengan parameter histopatologi

bronkiolus sampai pada alveoli paru.

Berdasarkan penelitian yang dilakukan oleh Kristianti (2004), didapat kelainan akibat radikal bebas pada pemaparan asap rokok subkronik berupa rusaknya silia pada permukaan epitel bronkus dan bronkiolus, adanya metaplasi epithel, hiperplasi kelenjar, dan terjadi peningkatan sel-sel radang. Di dalam tubuh sudah terdapat enzim yang dapat menangkal radikal bebas, namun bila jumlah radikal bebas berlebihan, seperti pada perokok, tubuh memerlukan antioksidan dari luar untuk menangkal radikal bebas (Edyson, 2003). Akhir-akhir ini antioksidan alami semakin diminati karena mempunyai tingkat keamanan yang lebih baik dibandingkan dengan antioksidan sintetik (Kumalaningsih, 2006).

Tanaman murbei (Morus multicaulis) mempunyai kandungan kimia berupa alkaloid, flavanoid (Sjamsijah, 1992), senyawa 1deoxynojirimycin (DNJ) (Sofian, 2005), mengandung bayak asam amino yaitu, dopamine, DOPAC, kynurenine, norepinephrine, trytophan, tyrosine, HPAC-4, dan L-DOPA, serat yang tinggi, ekdisteron, inkosteron, lupeol, $\beta$-sitosterol, ritin, morakatein, isoquersetin, skopoletin, skopolin, $\alpha$ heksenal, $\beta$-heksenal, cis- $\beta$-heksenol, cis- $\beta$-heksenol, cis-t-heksanol, benzaldehid, eugenol, linanol, benzil alkohol, butilamin, trigonelin, cholin, adenin, asam amino, vitamin $A$, vitamin $B$, vitamin $C$, karoten, asam fumarat, asam folat, asam formiltetrahidrofoli, mioinositol, logam seng dan tembaga (Hariana, 2011). Sebagaimana hal tersebut di atas, penelitian ini bertujuan untuk membuktikan apakah ekstrak etanol daun murbei terhadap tikus (Rattus norvegicus) jantan dapat mempengaruhi gambaran histopatologis paru-paru tikus yang diberi paparan asap rokok.

\section{METODE PELNELITIAN}

Penelitian ini dilakukan secara eksperimental dimana dilakukan pengujian antioksidan ekstrak etanol daun murbei (Morus multicaulis) dengan melihat histopatologis paruparu tikus (Rattus norvegicus) jantan yang dipapar asap rokok.

\section{Tempat Dan Waktu Penelitian}

Penelitian telah dilaksanakan pada bulan Mei sampai Juli 2012 yang bertempat di Laboratorium Farmakologi, Laboratorium Fitokimia Fakultas Farmasi Universitas Muslim Indonesia dan Balai Besar Veteriner Maros, Makassar. 
Pengaruh efek ekstrak etanol daun murbei sebagai antioksidan pada paru-paru tikus jantan yang dipapar asap rokok dengan parameter histopatologi

\section{Alat dan Bahan}

Alat yang digunakan dalam penelitian ini adalah Alat smoking pump, gelas kimia $\left(\right.$ Pyrex $\left.^{\circledR}\right)$, gelas piala $\left(\right.$ Pyrex $\left.^{\circledR}\right)$, kanula, spoit, Tissue Processor, Mikroskop Olympus Tipe BX 51, seperangkat alat maserasi, spoit, dan timbangan O'hauss $\left(\right.$ Camry $\left.{ }^{\circledR}\right)$.

Bahan - bahan yang digunakan dalam penelitian ini adalah Rokok kretek dengan kadar nikotin 2,2 mg dan kandungan tar 38 mg per batang rokok, air suling, etanol, minyak kelapa, Na. CMC (Natrium karboksil metilselulosa) vitamin E 100 iU dan ekstrak etanol daun murbei (Muros multicaulis).

\section{Prosedur Penelitian}

\section{Pembuatan Sampel}

Sebanyak 800 gr sampel daun murbei (Muros multicaulis) dimaserasi selama $5 \times 24$ jam dengan etanol 5000 $\mathrm{ml}$ dengan pengadukan beberapa kali, kemudian disaring dan ampasnya direndam kembali dengan cairan penyari yang baru, hasil penyarian yang diperoleh dipekatkan dengan menggunakan rotavapor sampai diperoleh ekstrak etanol kental dan ditimbang. Berat ekstrak kental yang diperoleh $32,9015 \mathrm{gr}$.

\section{Penyiapan Hewan Uji}

Hewan uji yang digunakan dalam penelitian ini adalah tikus (Rattus norvegicus) jantan yang sehat yaitu aktif dan lincah, bulunya tidak rontok dengan bobot badan 100 - 200 gram. Hewan uji terlebih dahulu diadaptasikan selama 2 minggu.

\section{Perlakuan Terhadap Hewan Uji}

a. Kelompok (P1) : kontrol positif yaitu tikus (Rattus norvegicus) yang diberi perlakuan aquadest dan makanan, tanpa diberikan paparan asap rokok dan tanpa pemberian ekstrak etanol daun murbei (Morus multicaulis).

b. Kelompok (P2) : kontrol negatif yaitu tikus (Rattus norvegicus) yang diberikan paparan asap rokok tanpa pemberian ekstrak etanol daun murbei (Morus multicaulis).

c. Kelompok (P3) : diberi paparan asap rokok dan ekstrak daun murbei (Morus multicaulis) sebanyak 100 mg/kgBB.

d. Kelompok (P4) : diberi paparan asap rokok dan ekstrak etanol murbei (Morus multicaulis) 200 $\mathrm{mg} / \mathrm{kgBB}$.

e. Kelompok (P5) : diberi paparan asap rokok dan vitamin $\mathrm{E} \quad 1,8$ $\mathrm{mg} / \mathrm{kgBB}$. 
Pengaruh efek ekstrak etanol daun murbei sebagai antioksidan pada paru-paru tikus jantan yang dipapar asap rokok dengan parameter histopatologi

f. Perlakuan selama 31 hari, pada paru tikus untuk uji histopatologi.

hari ke 31 tikus diambil organ paru-

\section{HASIL PENELITIAN}

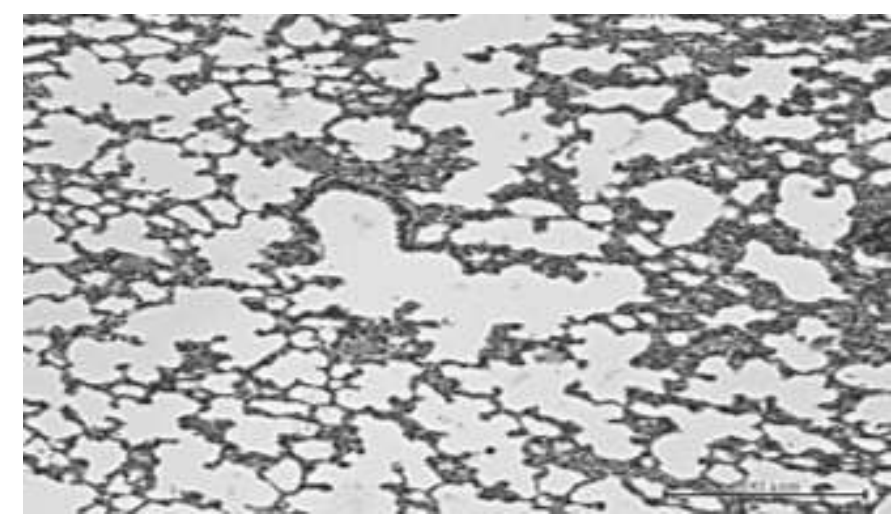

Gambar 1. Foto hasil histologi paru-paru tikus putih (Rattus norvegicus) kontrol positif dengan pembesaran $20 x$

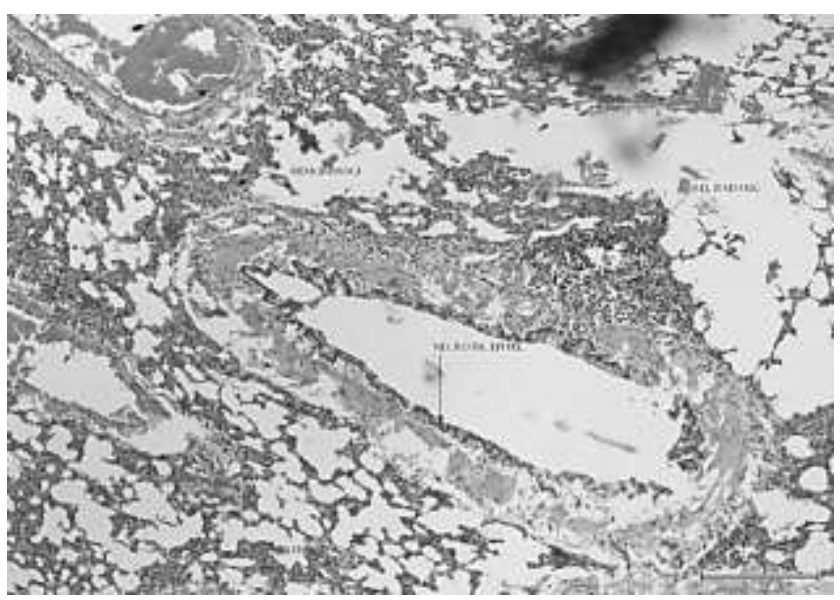

Gambar 2. Foto hasil histologi paru-paru tikus putih (Rattus norvegicus) kontrol negatif dengan pembesaran 20x.

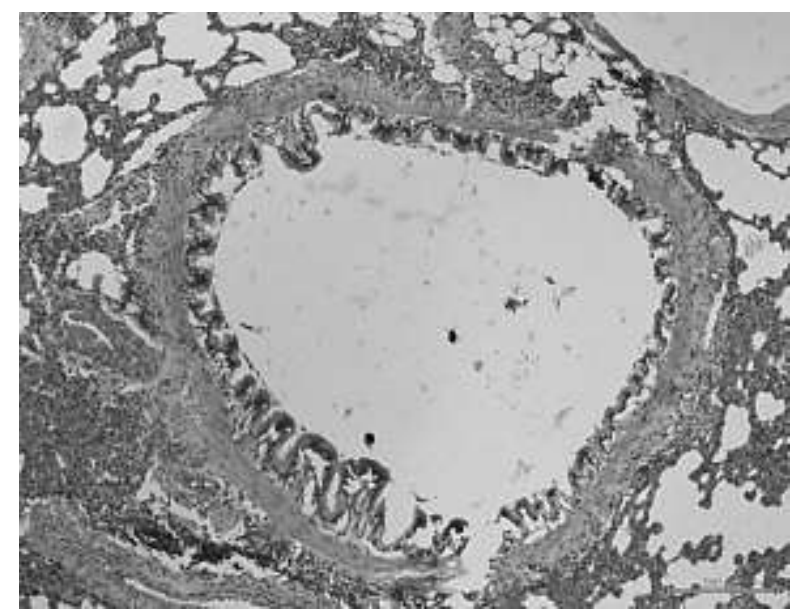

Gambar 3. Foto hasil histologi paru-paru tikus putih (Rattus norvegicus) yang telah diberikan ekstrak murbei dengan dosis $100 \mathrm{mg} / \mathrm{kgBB}$ dengan pembesaran 20x 
Pengaruh efek ekstrak etanol daun murbei sebagai antioksidan pada paru-paru tikus jantan yang dipapar asap rokok dengan parameter histopatologi

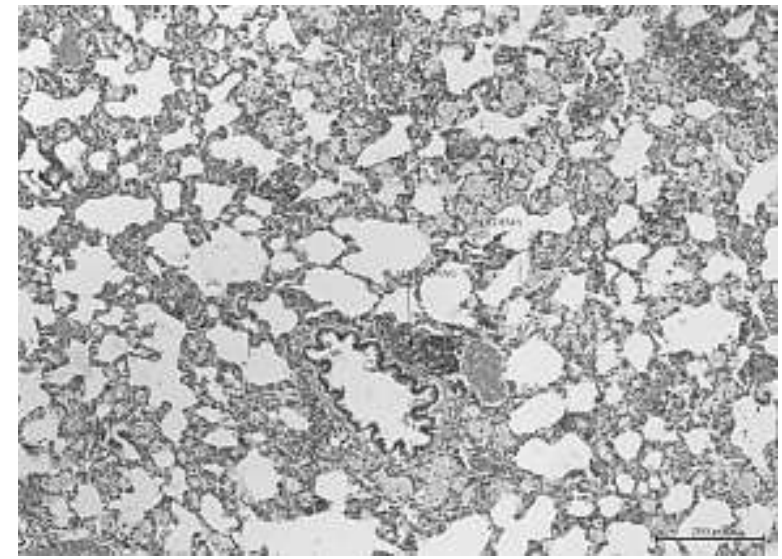

Gambar 4. Foto hasil histologi paru-paru tikus putih (Rattus norvegicus) yang telah diberikan ekstrak murbei dengan dosis $200 \mathrm{mg} / \mathrm{kgBB}$ dengan pembesaran 20x

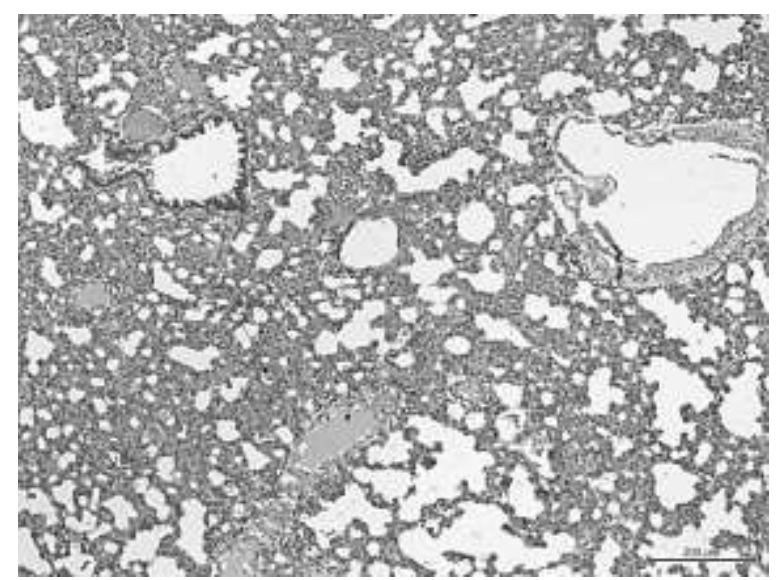

Gambar 5. Foto hasil histologi paru-paru tikus putih (Rattus norvegicus) yang telah diberikan vitamin $\mathrm{E}$ dengan dosis $1,8 \mathrm{mg} / \mathrm{kgBB}$ dengan pembesaran 20x.

\section{PEMBAHASAN}

Dalam penelitian ini hewan uji yang digunakan adalah tikus kelamin jantan, umur 2 -3 bulan dengan berat 100 - 200 gram sebanyak 25 ekor. Tikus adalah hewan uji yang sering digunakan dalam percobaan atau penelitian biomedis, karena harganya relatif murah, mudah berkembang biak, tidak mudah mati, selain itu pemeliharaannya juga mudah.

Hasil pengamatan histologi pada kelompok kontrol positif tidak terdapat kerusakan paru-paru yang berarti sel dalam keadaan normal (Gambar 1). Kelompok kontrol negatif terdapat kerusakan paru-paru yang berarti sel dalam keadaan tidak normal, seperti congesti, hemorrhagi, necrotik epitel dan sel radang (Gambar 2). Kelompok yang diberikan ekstrak etanol daun murbei dengan dosis 100 $\mathrm{mg} / \mathrm{KgBB}$ berdasarkan analisis deskriptif histologi paru hanya mengalami sel radang pada paru-paru (Gambar 3). Kelompok yang diberikan ekstrak etanol daun murbei dengan dosis $200 \mathrm{mg} / \mathrm{KgBB}$ terdapat 
Pengaruh efek ekstrak etanol daun murbei sebagai antioksidan pada paru-paru tikus jantan yang dipapar asap rokok dengan parameter histopatologi

kerusakan pada paru-paru berupa hemorrhagi, dedema dan sel radang (Gambar 4). Kelompok yang diberikan dengan vitamin $\mathrm{E}$ terdapat kerusakan paru-paru berupa hemorrhagi (Gambar $5)$.

Pada kelompok perlakuan diberi zat yang mempunyai khasiat sebagai antioksidan sehingga dapat meredan aktivitas radikal bebas. Ekstrak daun murbei (Morus multicaulis) dosis 100 $\mathrm{mg} / \mathrm{kgBB}$ dan $200 \mathrm{mg} / \mathrm{kgBB}$ berfungsi sebagai antioksidan karena mengandung zat-zat yang mempunyai khasiat antioksidan seperti senyawa flavanoid, vitamin $A$, vitamin $B$, vitamin C, karoten, asam folat. Senyawa tersebut merupakan komponen dengan aktivitas antioksidan pada ekstrak daun murbei memiliki kemampuan menagkap dan menstabilkan radikal bebas.

Kelompok kontrol positif tidak mendapatkan paparan asap rokok mempunyai kepadatan permukaan paru dimana diameter alveolus masih normal. Dibandingkan dengan kelompok negatif yang mendapatkan paparan asap rokok dimana alveolusnya melebar. Sel paru yang terpapar asap rokok mengalami perubahan patologis seperti pelebaran dinding alveolus. Pelebaran alveolus diawali oleh oksidasi protein yang menyebabkan ketidakseimbangan enzim proteolisis dan antiproteolisis pada paru sehingga kehilangan integritas dan kemampuan elastisitasnya. Dimana enzim proteolisis ini dapat menyebabkan emfisema atau perdangan.

\section{KESIMPULAN}

Disimpulkan bahwa pemberian ekstrak etanol daun murbei (Morus multicaulis) dosis $100 \mathrm{mg} / \mathrm{kgBB}$ dan $200 \mathrm{mg} / \mathrm{kgBB}$ dapat memberikan efek sebagai antioksidan.

\section{DAFTAR PUSTAKA}

Depkes. 2005. Merokok dan Promosi Kesehatan. http:// www. promosikesehatan.com /artikel. php?nid=122. Diakses 10 mei 2012.

Edyson. 2003. Pengaruh Pemberian Vitamin $C$ dan E Terhadap Aktifitas Kadar MDA pada Eritrosit Rattus Novergicus Galur Wistar yang Diinduksi Ltiroksin. Unair, Surabaya.

Ganiswarna, S.G., 2007. Farmakologi dan Terapi. Edisi V. Bagian Farmakologi Fakultas Kedokteran, Universitas Indonesia, Gaya Baru, Jakarta.

Hariana, A., 2007. Tumbuhan Obat dan Khasiatnya seri 2. Penebar Swadaya, Jakarta..

Kristianti, C., 2004. Pengaruh Tempe Kedelai Terhadap Struktur Histopatologis Bronkus dan Bronkiolus Tikus Rattus novergicus galur Wistar yang dipapar Asap Rokok Subakut. 
Pengaruh efek ekstrak etanol daun murbei sebagai antioksidan pada paru-paru tikus jantan yang dipapar asap rokok dengan parameter histopatologi

Tugas Akhir. Universitas

Brawijaya, Malang

Kumalaningsih, S., 2006. Anti Oksidan Alami. Trubus Agri sarana, Surabaya.

Lawrence, G., 1951. Taxonomy of Vascular Plants. Macimilan ; New York. http://eprints.undip.ac.id/32168/ 6/B04 Sendy Septina chapter ll.pdf .

Malole, M.B.M., Pramono, C.S.U., 1989. Penggunaan HewanHewan Percobaan di Laboratorium. Departemen Pendidikan dan Kebudayaan Direktorat, Jakarta.

Sjamsijah. 1992. Petunjuk Teknis Budidaya Murbei. Pusat
Penelitian dan Pengembangan Hutan dan Konservasi Alam,. Bogor

Sofian, T., 2005. Senyawa DNJ, Calon Obat Diabetes dari Murbei. Berita Iptek. http:// journal .ipb.ac.id/index.php/igizipangan/ article/viewFile/4452/2989.

Winarsih, H., 2007. Antioksidan Alami dan Radikal Bebas. Penerbit Kanisius, Yogyakarta.

Yuniwati, Y., Mulhyohadi, A., 2004. Pengaruh Paparan Asap Rokok Kretek Terhadap Peroksidasi Lemak Dan system Proteksi Superoksid Dismutase Hepar Tikus Wistar. Jurnal Kedokteran YARSI $12: 89$. 